\title{
INTRA-ALIMENTARY DRIP FEEDING FOLLOWING PARTIAL GASTRECTOMY
}

\author{
By Maurice Lee, M.B., B.S., F.R.C.S. \\ Senior Surgeon Upton Hospital, Slough, and Visiting Consulting Surgeon Iver, Denham and Langley Hospital, Windso o \\ Group, North West Metropolitan Region.
}

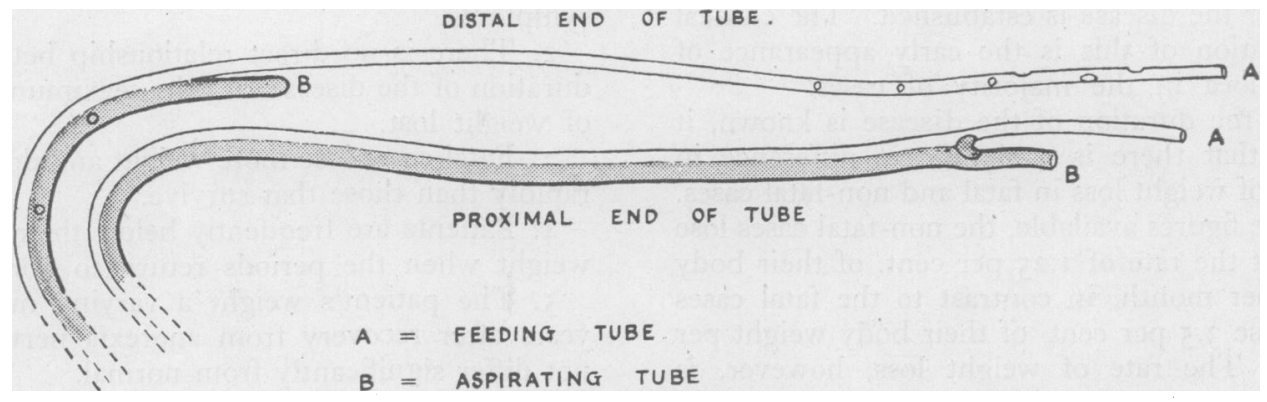

Fig. 1.-Twin Tube.

Following operation for partial gastrectomy it is usual for the patient to leave the operating table with a Ryle's tube in the stomach and a needle in a vein, through which are given normal saline or glucose saline, and in some cases blood.

The dangers of giving post-operative intravenous fluids has been stressed over and over again in recent years. It is known that a patient can die from too much fluid administered into the venous circulation, one reason being that it is difficult to know clinically how much fluid is needed, and the amount given is therefore more or less guesswork.

In the past it was felt that to give fluids into the intestine following an operation for partial gastrectomy would be against all the principles of surgical practice. The opinion is held that following an abdominal operation the intestines are in a state of temporary ileus, and that to put fluid into a bowel in this state is harmful. However, the writer has observed constantly, whilst carrying out an anastomosis of the jejunum to the remaining portion of the stomach that the jejunum shows no evidence of ileus, but on the contrary an active peristalsis is present. This clinical impression was confirmed by passing small quantities of a dilute barium solution down the feeding tube on the day following operation, and the barium was seen to reach the lower ileum within four hours.
It was therefore considered that intra-aliment drip feeding was the method of choice after parkat gastrectomy, but that the method could $\bar{B}$ improved to avoid the risk of leaking at suture lines or of gastric retention. A 'twin tube $\frac{\bar{O}}{O}$ was devised which enabled post-operative gastrie aspirations to accompany alimentary feeding at 8 site beyond the anastomosis, where the operation was a Billroth I or Polya-type.

The tube itself (Fig. I) consists of a two-wat tube, the larger being a Ryle's tube for the puro poses of aspiration of the stomach if needed. Thi smaller tube, which is vulcanized to the Ryle' tube, is roughly $3 \mathrm{~mm}$. in diameter, or 4 Englis catheter guage, and projects 8 in. beyond the en⿳亠丷厂巾. of the Ryle's tube. Several perforations are mads in the terminal 4 in., and it is used for feeding The end of the Ryle's tube remains in the gastrio remnant, while the end of the other tube projects 8 in. beyond the anastomosis into the duodenuri or jejunum, depending on the type of operatio $\overline{\bar{B}}$ performed. This tube (Maurice Lee Two-way) Tube) (Fig. 2) is fed into the stomach prior to operation through the nose in the usual mannet⿱ and while the resection is being performed it is manually guided into its permanent quarters the time of constructing the anastomosis. The tube is opaque to X-rays and confirmation of its position can thus be ascertained by means of straight X-ray if it should be needed. 


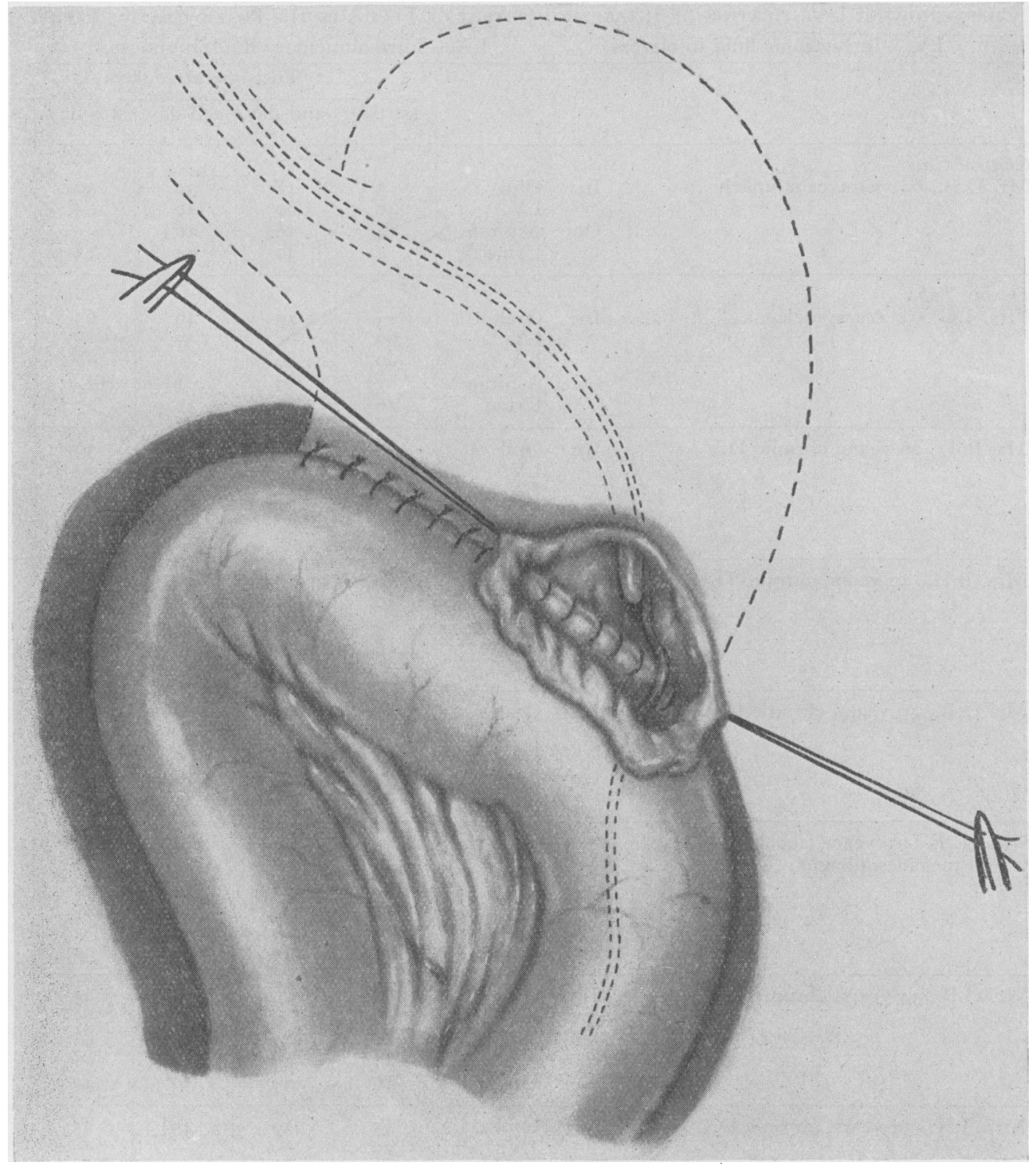

FIG. 2.-Semi-diagrammatic illustration showing tube in situ prior to the completion of the closure of the anatomosis. Note feeding element of tube going over the stoma into the efferent loop of the bowel.

As usual the patient has an intravenous drip put up during the anaesthetic. This is to be considered as part of the anaesthesia, as the fluid given this way is solely to combat any shock which may ensue during the operation, and in addition it allows the anaesthetist to give any drug which he wishes to use during the period of anaesthesia.

As soon as the operation is over and the anaesthetist no longer needs to give any more intravenous fluids, these are stopped and the drip apparatus is switched from the intravenous needle to the feeding member of the two-way tube. At the most two bottles of physiological saline will be given during the operation. Most often only one bottle is needed. After the intravenous administration is stopped, a mixture of $\frac{1}{2} \mathrm{oz}$. Casilan to one pint of tapwater is given into the intestine at the same speed at which the intravenous drip is administered. In this way a large amount of protein is fed to the patient in the immediate post-operative period-a time 
Chart showing Investigation of Intake and Output of Fluids in the Post-operative Period I.V.-Intravenous fluid in ounces. I.A.-Intra-alimentary fluid in ounces.

\begin{tabular}{|c|c|c|c|c|c|c|c|c|c|}
\hline \multirow[b]{2}{*}{$\begin{array}{l}\text { Case } \\
\text { No. }\end{array}$} & & \multicolumn{5}{|c|}{ Post-operative days } \\
\hline & & & & & Ist day & 2nd day & 3rd day & $4^{\text {th }}$ day & $5^{\text {th }}$ day \\
\hline I. & $\begin{array}{l}\text { Control Case } \\
\text { Mr. D.B., } 64 \text { years, ca stomach. . }\end{array}$ & $\cdots$ & $\begin{array}{l}\text { In: } \\
\text { Out: }\end{array}$ & $\begin{array}{l}\text { Oral } \\
\text { I.V. } \\
\text { Aspirate } \\
\text { Urine }\end{array}$ & $\begin{array}{c}3 \\
4^{\circ} \\
14 \frac{1}{2} \\
4\end{array}$ & $\begin{array}{l}18 \\
60 \\
18 \frac{3}{4} \\
30\end{array}$ & $\begin{array}{l}32 \\
40 \\
10 \frac{1}{2} \\
14\end{array}$ & $\frac{30}{14}$ & 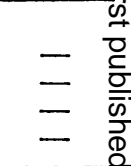 \\
\hline 2. & $\begin{array}{l}\text { Double Tube } \\
\text { Mrs. J.G., 50 years, melaena }\end{array}$ & $\cdots$ & $\begin{array}{l}\text { In: } \\
\text { Out: }\end{array}$ & $\begin{array}{l}\text { Oral } \\
\text { I.V. } \\
\text { I.A. } \\
\text { Aspirate } \\
\text { Urine }\end{array}$ & $\begin{array}{l}\overline{60} \\
40 \\
I \frac{1}{2} \\
26\end{array}$ & $\begin{array}{l}15 \\
80 \\
7 \\
40\end{array}$ & $\frac{\frac{46}{-}}{4^{\frac{1}{2}}}$ & $\frac{\frac{63}{-}}{27}$ & $\begin{array}{l}=\vec{\circ} \\
=\overrightarrow{\vec{\omega}} \\
=\frac{\mathrm{o}}{\overline{0}}\end{array}$ \\
\hline 3. & Mr. B.T., 26 years, chronic D.U. & . & $\begin{array}{l}\text { In: } \\
\text { Out: }\end{array}$ & $\begin{array}{l}\text { Oral } \\
\text { I.V. } \\
\text { I.A. } \\
\text { Aspirate } \\
\text { Urine }\end{array}$ & $\begin{array}{l}- \\
20 \\
40 \\
33 \\
-\end{array}$ & $\begin{array}{l}16 \\
80 \\
14 \frac{1}{2} \\
36\end{array}$ & $\frac{26}{\frac{7}{37}}$ & $\frac{30}{\frac{2}{25}}$ & 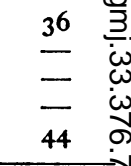 \\
\hline 4. & Mrs. B.H., 42 years, chronic D.U. & . . & $\begin{array}{l}\text { In: } \\
\text { Out: }\end{array}$ & $\begin{array}{l}\text { Oral } \\
\text { I.V. } \\
\text { I.A. } \\
\text { Aspirate } \\
\text { Urine }\end{array}$ & $\begin{array}{l}- \\
40 \\
80 \\
15 \\
\end{array}$ & $\begin{array}{l}18 \\
80 \\
19 \frac{1}{2} \\
36\end{array}$ & $\frac{19}{\frac{19}{38}}$ & $\frac{20}{-}$ & 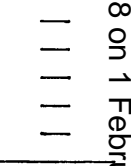 \\
\hline 5. & Mr. D.B., 40 years, chronic D.U. & . & $\begin{array}{l}\text { In: } \\
\text { Out: }\end{array}$ & $\begin{array}{l}\text { Oral } \\
\text { I.V. } \\
\text { I.A. } \\
\text { Aspirate } \\
\text { Urine }\end{array}$ & $\begin{array}{r}6 \\
40 \\
65 \\
7 \frac{1}{2} \\
22 \\
\end{array}$ & $\begin{array}{r}13 \\
60 \\
7 \\
20\end{array}$ & $\begin{array}{l}\frac{40}{60} \\
11 \\
24\end{array}$ & $\begin{array}{r}15 \\
5 I \\
3 I \\
8 \\
\end{array}$ & 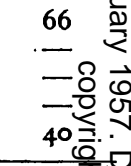 \\
\hline 6. & $\begin{array}{c}\text { Mrs. E.F., } 65 \text { years, achalasia of ca } \\
\text { and megaoesophagus .. }\end{array}$ & dio & $\begin{array}{l}\text { In: } \\
\text { Out: }\end{array}$ & $\begin{array}{l}\text { Oral } \\
\text { I.V. } \\
\text { I.A. } \\
\text { Aspirate } \\
\text { Urine }\end{array}$ & $\begin{array}{r}- \\
90 \\
11 \\
4 \\
26\end{array}$ & $\begin{array}{c}\bar{Z} \\
120 \\
9 \frac{1}{2} \\
35\end{array}$ & $\begin{array}{l}- \\
100 \\
104^{\frac{1}{2}}\end{array}$ & $\begin{array}{l}\frac{-}{120} \\
4^{\frac{1}{2}}\end{array}$ & $\begin{array}{ll}\frac{49}{3} & \frac{\sum}{0} \\
\frac{60}{0} & \frac{0}{D} \\
40 & \frac{2}{\#}\end{array}$ \\
\hline 7 . & Mr. G.P., 54 years, chronic D.U. & . & $\begin{array}{l}\text { In: } \\
\text { Out: }\end{array}$ & $\begin{array}{l}\text { Oral } \\
\text { I.V. } \\
\text { I.A. } \\
\text { Aspirate } \\
\text { Urine }\end{array}$ & $\begin{array}{r}6 \\
60 \\
40 \\
7 \\
19 \\
\end{array}$ & $\begin{array}{l}19 \\
80 \\
50 \\
29\end{array}$ & $\begin{array}{l}\frac{22}{60} \\
15 \frac{1}{2} \\
30\end{array}$ & $\frac{45}{-}$ & $\begin{array}{l}68 \\
\text { 二 } \\
\text { 三 } \\
\text { 三 } \\
59 \\
\end{array}$ \\
\hline 8. & Mrs. J.K., 32 years, chronic D.U. & . & $\begin{array}{l}\text { In: } \\
\text { Out: }\end{array}$ & $\begin{array}{l}\text { Oral } \\
\text { I.V. } \\
\text { I.A. } \\
\text { Aspirate } \\
\text { Urine }\end{array}$ & $\begin{array}{c}5 \\
20 \\
120 \\
23 \frac{1}{2} \\
-\end{array}$ & $\begin{array}{l}19 \\
80 \\
15 \\
73\end{array}$ & $\begin{array}{c}\frac{45 \frac{1}{2}}{20} \\
8 \\
36 \frac{1}{2}\end{array}$ & $\frac{\frac{45}{-}}{24}$ & $\begin{array}{l}= \\
\bar{Z}\end{array}$ \\
\hline
\end{tabular}

when much nitrogen loss is taking place. In this manner as much as $60 \mathrm{~g}$. of protein can be taken in by the patient in the first 24 hours. This is continued until about the end of the third day, when the tube is removed, and normal feeding is commenced. The Casilan requires careful straining to prevent its blocking the tube.

There is little risk of overloading the circulation by giving fluids into the bowel. But there are other reasons for adopting this method, one being that there is not the risk of giving the patient a thrombosis or thrombo-phlebitis. Although this is rare in intravenous therapy into an arm vein, if does occur frequently when the needle is intro duced into a leg vein. These thrombotic vein: often remain painful or tender for quite a times Again there is no likelihood of the needle becoming blocked, or coming out of the vein unnoticed both of which occurrences are common wits intravenous administration unless there is constant ${ }^{+}$ supervision.

Sometimes after an anastomosis has bee 
carried out, the stoma becomes temporarily oedematous and swollen, so causing some retention of stomach contents behind it. The small feed tube going through the anastomosis safeguards against this temporary blockage.

Finally, electrolytes and potassium replacement are given from the commencement, to ensure against any deficiency of these which might lead to ileus.

It has been found that as much as 6 pints of fluid can be absorbed from the intestine in 24 hours by the use of an intra-alimentary drip. Usually, however, the amount of fluid administered is in the neighbourhood of 4 pints. That this fluid is absorbed is shown by the estimations which were carried out on the blood sodium, potassium and chlorides, both prior to operation and in the immediate post-operative period when the drip was being given into the intestine. The pre- and post-operative readings were indentical.

In the first gastrectomy in which the Twin-tube was tried only glucose saline was given into the intestine, and the writer was so impressed with the comfort of the patient, the lack of thirst and absence of any sign of dehydration, that it was decided to administer the mixture of Casilan in all subsequent gastrectomies, thus feeding the patient from the beginning with proteins, fluids and electrolytes into the intestine. There is no doubt whatsoever that this form of therapy has proved itself far superior to the intravenous method of therapy which is the usual practice.

\section{Summary}

Intra-alimentary drip fèeding has been insti- tuted as a routine in all cases of partial gastrectom Its advantages over intravenous therapy are:

I. There is no risk of overloading the body wit fluids, the intestines being selective in the amount of'fluids to be absorbed.

2. There is no risk of thrombo-phlebitis, an $\overrightarrow{\vec{a}}$ no escape of fluid through a needle slipping oa of a vein.

3. Electrolytes, proteins and fluids are give by the natural route, and in addition protein los following operation is immediately replaced.

4. The stoma of the stomach is safeguarded. during the period when oedematous swelling may temporarily occlude it. This applies particularl+ to the Billroth I type of gastrectomy.

5. The intra-alimentary drip tube does aw⿳亠ेषे with the necessity of any tube being attached to. the patient in the immediate post-operative period, other than the two-way tube, whicb replaces the usual Ryle's tube.

6. All gastric aspirations can be returned to thid intestines by the feeding element of the tubes This is important to conserve essential electrolytes.

I am indebted to the many medical colleagues and sisters who so kindly co-operated with me is the series of cases which were performed Upton Hospital, Slough.

The Two-way tube was made for me by the co-operation of Messrs. A. C. Daniels \& Comp ing Limited, of London, and I am indebted to theng for all the help they have given me.

\section{BIBLIOGRAPHY}

McDONALD, H. A. (1954), Lancet, May 15, p. 1007. WILKINSON, A. W. (1950), et al., Lancet, i, 533. WILKINSON, A. W. (1949), et al., Lancet, i, 640.

\section{NOTICE OF SPECIAL INTEREST TO SUBSCRIBERS:}

'WHY NOT HAVE YOUR COPIES OF THIS
JOURNAL BOUND INTO YEARLY VOLUMES?'

You can have your twelve monthly issues fully bound in dark green pin head cloth. lettered in silt on spine with name of Journal, Volume Number and year, complete with index at front, for 21s. Od. post free. A limited number of out of prine journals are available to bind into volumes and make your library complete. Price on application siving details of issues required to complete back volumes.

THE FELLOWSHIP OF POSTGRADUATE GO PORTLAND PLACE, LONDON. W.I

\section{WHY NOT HAVE YOUR JOURNALS BOUND?}

Manufacturers' Notes continued from page 88.

the outside the entrant's nom-de-plume; these envelopes will not be opened until after judging has been completed.

Closing date for entries each year will be July 3I. The first award will be made in 1957. Entries must be addressed to:- The Chairman of
MEDICINE

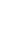

